\title{
Gallbladder Hydatid Cyst: A Review on Clinical Features, Investigations and Current Management
}

This article was published in the following Dove Press journal:

Clinical and Experimental Gastroenterology

\author{
Vipul D Yagnik (D) \\ Sushil Dawka (iD) ${ }^{2}$ \\ Nitin Patel ${ }^{3}$
}

'Department of Surgical Gastroenterology, Nishtha Surgical Hospital and Research Centre, Patan, Gujarat, India; ${ }^{2}$ Department of Surgery, SSR Medical College, Belle Rive, Mauritius; ${ }^{3}$ Department of Surgical Gastroenterology, Gujarat Superspeciality Hospital, Baroda, Gujarat, India

\section{Video abstract}

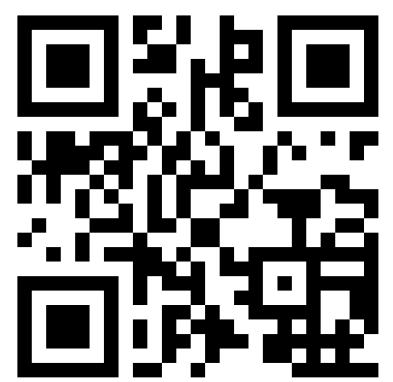

Point your SmartPhone at the code above. If you have a $Q R$ code reader the video abstract will appear. Or use: https://youtu.be/Sc07608nEOY
Correspondence: Vipul D Yagnik Department of Surgical Gastroenterology, Nishtha Surgical Hospital and Research Centre, Patan, Gujarat 384265, India Email vipul.yagnik@gmail.com
Background: Gallbladder hydatid cyst (GBHC) is highly uncommon with an incidence of $0.3-0.4 \%$ of all atypically located hydatid cysts. Our personal experience of one case of primary GBHC (PGBHC) managed laparoscopically motivated this systematic review. This study aimed to analyze the demographic characteristics, types [whether primary GBHC (PGBHC) or secondary GBHC (SGBHC)], clinical presentation, laboratory investigations, imaging studies, operative procedure, hospital stay, follow-up and recurrence.

Methods: A systematic review was performed using preferred reporting items for systematic reviews and meta-analyses guidelines.

Results: Twenty studies, including 22 cases plus one more case managed by us, were included in the review. For PGBHC, the mean age was 48.61 years while for SGBHC it was 47.9 years. PGBHC was more common in females $(69.23 \%)$ while SGBHC was more common in males $(55.55 \%)$. Overall, GBHC was more common in females $(56.52 \%)$. The most common presentation overall was abdominal pain $(100 \%)$ followed by nausea/vomiting $(43.47 \%)$. The other common symptoms were nausea/vomiting $(61.53 \%)$ and Murphy's sign (38.46\%) in PGBHC, but jaundice (50\%) and fever $(30 \%)$ in SGBHC. In PGBHC, 50\% patients had normal liver function while this was deranged in $66.66 \%$ patients with SGBHC. Serology was positive in $50 \%$ of PGBHC and $100 \%$ in SGBHC. Ultrasonography was positive in $50 \%$, while CT-scan showed $70 \%$. CT-scan was better at detection of SGBHC (100\%). The most common operation was open cholecystectomy (78.26\%) either isolated or combined. Isolated open cholecystectomy was commonly done in PGBHC (69.23\%). Overall, only $56.52 \%$ of patients received albendazole, but no recurrence was reported. The average hospital stay was 7.25 days and follow-up ranged from 1 month to 10 years.

Conclusion: GBHC mostly affects females with abdominal pain being the most common symptom. Ultrasonography is expedient though CT-scan is more sensitive. Albendazole monotherapy has questionable value. Open cholecystectomy is the most common operation. However, laparoscopy is safe in experienced hands.

Keywords: hydatid, cyst, gallbladder, primary, secondary

\section{Introduction}

Human hydatid disease is a zoonotic infection caused by the larval form of Echinococcus granulosus (95\%), though Echinococcus multilocularis is responsible in fewer than $5 \%$ of cases. ${ }^{1}$ It is endemic in sheep and cattle-raising regions. The parasite is found in the small intestine of the definitive hosts like dogs and foxes and is transmitted to the intermediate hosts such as sheep and humans by ingestion of ova in feces. After ingestion, the embryonic form of the parasite passes to the liver via the portal vein. If it escapes trapping in the liver (first filter), the second 
most frequent location is the lung (second filter). If the embryos escape the liver and lung filters or by-pass them via lymphatics, this results in hematogenous and lymphatic dissemination. Thereafter, the embryo can lodge in any part of the body and develop into the larval stage. ${ }^{2}$

Atypical locations reported for hydatid cyst include the spleen, kidney, peritoneum, retroperitoneum, pancreas, gallbladder, inguinal region, cerebral hemispheres, spinal cord, mediastinum and seminal vesicle. ${ }^{3}$

Primary GBHC is an extremely uncommon phenomenon. It is defined as GBHC without any history of hydatid disease in the past, as well as no hydatid cyst found at any other location during surgery. ${ }^{4}$ Secondary GBHC occurs along with a hydatid cyst in another site, most often the liver.

This review aims to analyze the demographic characteristics, clinical presentation, laboratory investigation, imaging studies, operative procedure, hospital stay, and follow-up concerning both primary and secondary GBHC.

\section{Materials and Methods}

A systematic review was performed using preferred reporting items for systematic reviews and meta-analyses principles. ${ }^{5}$ Studies were identified by searching electronic databases like MEDLINE/PubMed, EMBASE, Semantic Scholar and Cochrane Review in December 2019 and performing Google Scholar search. The search terms used included "primary gallbladder hydatid cyst", "primary gallbladder hydatid disease", "secondary gallbladder hydatid cyst", and "secondary gallbladder hydatid disease". Studies and reports published in languages other than English or original articles reporting GBHC but lacking enough information for analysis were excluded from the review. On initial search, we found 1371 articles; duplicates and irrelevant publications were 1334 and were eliminated after title, abstract, and full-text review. Seventeen more non-English language items were excluded because of unavailability of translated full text. We added one more case that was treated by us. Finally, there were 20 articles, comprising 22 patients who, along with an additional case managed by us, were considered for review (Figure 1). To our knowledge, this is the first review where GBHC is analyzed differently based on primary or secondary occurrence. A total of 23 cases were investigated: for 22 cases data extraction was performed using a standardized form and included the year of publication, age/sex, clinical features, laboratory investigations, pre-operative imaging, operative procedure, hospital stay, medical management, follow-up and recurrence.

\section{Case Details of Our Patient}

A 35-year-old female presented to our surgical outpatient department with complaints of right upper quadrant pain, accompanied by nausea and occasional vomiting. There was a history of $H$. pylori infection in the past, for which she was treated for 14 days with no relief. She had no history of jaundice or high-grade fever. Physical examination showed mild tenderness in the right upper quadrant of the abdomen. Routine blood investigation, liver function, and renal function tests were normal. Tumor markers like CA 19-9 and alpha-fetoprotein were also within normal limits. Ultrasonography of the abdomen revealed a cystic lesion in the right lobe of the liver. Computed tomography of the abdomen showed mild hepatomegaly and a well-defined cystic density lesion in segments IVa/IVb of the liver with mild exophytic component apparently abutting the adjacent gallbladder suggesting liver hydatid cyst (Figure 2). It measured $2.3 \mathrm{~cm}$ (anteroposterior) $\times 2.4 \mathrm{~cm}$ (mediolateral) $\times 2.4 \mathrm{~cm}$ (craniocaudal) and showed internal septations, septal and peripheral calcification and slight peripheral and septal enhancement on post-contrast scan. The gallbladder was distended, with no hyperdense calculi or mass lesion detected in the lumen. We suspected a hepatic hydatid cyst abutting the gallbladder and decided to proceed with diagnostic laparoscopy followed by extended cholecystectomy. Laparoscopy revealed minimal inflammation of the gallbladder, so we decided to perform laparoscopic cholecystectomy (Figure 3). On opening the specimen, the daughter hydatid cyst was identified (Figure 4). The postoperative course was unremarkable, and we discharged the patient on the third postoperative day. The patient has been on follow-up for three months without any problem.

\section{Results}

A total of 23 cases comprising one patient from personal experience and 22 patients derived from 20 eligible studies identified by literature search were analyzed (Table 1-4).

\section{Demographic Characteristics}

PGBHC (Table 1): It was uncommon before 30 years (7.69\%) but more common after 50 years $(61.53 \%)$. The mean age was 48.61 years and ranged from 16-68 years. It was more common in females (nine cases: $69.23 \%$ ) as compared to males (four cases: $30.76 \%$ ). 


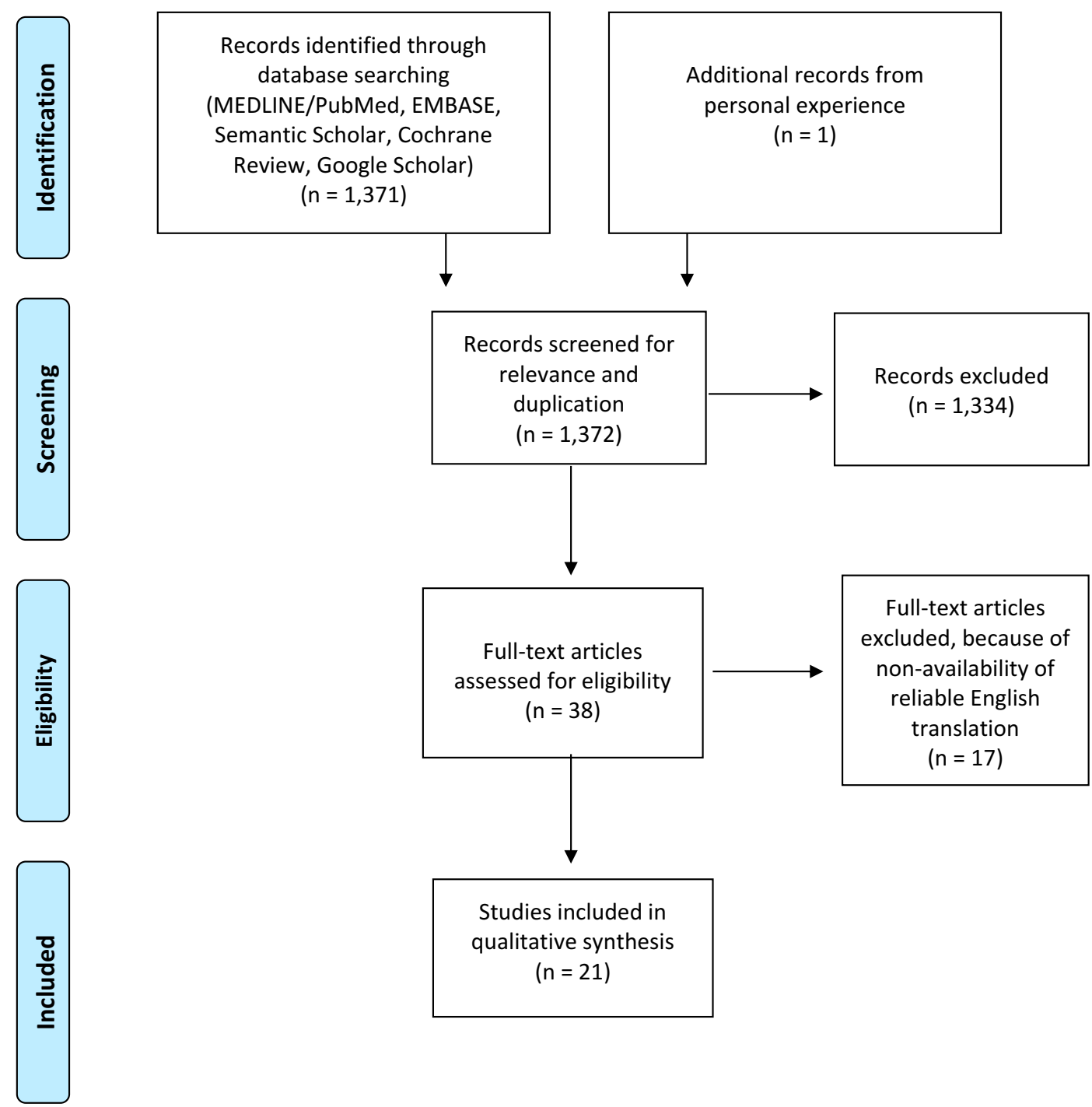

Figure I Preferred reporting items for systematic reviews and meta-analyses (PRISMA) 2009 flow diagram: gallbladder hydatid cyst: literature search.

SGBHC (Table 3): Only $20 \%$ of patients were under 30 years. The mean age was 47.9 years and it ranged between 27-76 years. It was slightly more common in males (five of nine cases: $55.55 \%$ ). The gender of one patient was not recorded.

\section{Clinical Features}

PGBHC (Table 1): Among these, abdominal pain was the most common presenting symptom seen in 13/13 (100\%) cases. Other symptoms included nausea/vomiting in $8 / 13$ cases $(61.53 \%)$ and Murphy's sign in 5/13 cases (38.46\%). Fever was present in 3/13 cases $(23.07 \%)$ and jaundice in $1 /$ $13(7.69 \%)$.

SGBHC (Table 3): Abdominal pain was seen in all ten patients $(100 \%)$, nausea in two $(20 \%)$, while three patients
(30\%) had fever, and five patients (50\%) had jaundice. Weight loss was seen in $20 \%$ cases, and history of hydatid cyst in $20 \%$. Murphy's sign was positive in $10 \%$ cases.

\section{Laboratory Investigations}

PGBHC (Table 1): $50 \%$ patients (6/12) had normal laboratory investigations. Eosinophilia was seen in 3/12 patients (25\%) cases and leukocytosis was also observed in $25 \%$ cases. Altered liver function test was seen in one patient $(7.69 \%)$. We were unable to find laboratory investigations for one patient.

SGBHC (Table 3): Six patients had altered LFTs $(66.66 \%)$. Investigations were normal in three patients $(33.33 \%)$. Investigations were not available for one patient. 


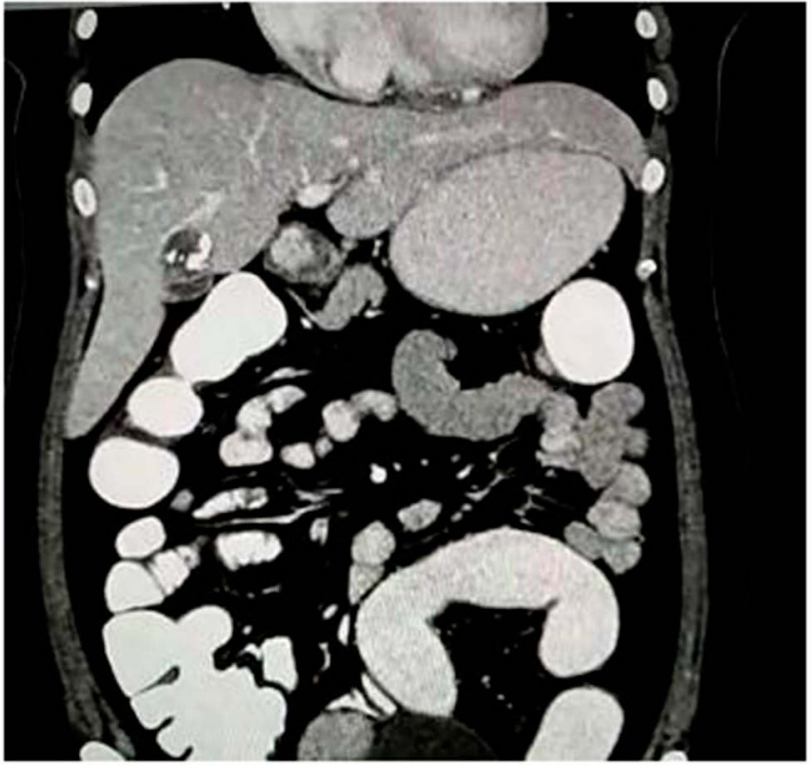

Figure 2 Computed tomography (CT) scan showing well-defined cystic lesion with internal septations and septal and peripheral calcification in segments $\mathrm{IVa} / \mathrm{IVb}$ of the liver.

\section{Serology}

PGBHC (Table 1): Serology was performed in only four $(30.76 \%)$ cases; $50 \%$ cases were seropositive.

SGBHC (Table 3): Serology was performed in only three cases, all of which were positive.

\section{Imaging Studies}

Primary GBHC (Table 1): Ultrasonography of the abdomen was performed in 10/13 (76.92\%) patients, computed tomography of the abdomen in 6/13 cases (46.15\%). MRCP/MRI was performed in $2 / 13$ cases $(15.38 \%)$. The pre-operative diagnosis of hydatid cyst was possible in $7 / 13$ cases (53.84\%). Out of 10 cases of USG, $4(40 \%)$ had a preoperative diagnosis. Out of six cases, CT-scan was able to diagnose hydatid cyst pre-operatively in three cases $(50 \%)$. MRCP/MRI was able to diagnose preoperatively in one of two cases $(50 \%)$. Only USG was performed in four $(30.76 \%)$ cases, USG+CT+MRCP was performed in two $(15.38 \%)$ cases, USG+CT in two cases (15.38\%).

Secondary GBHC (Table 3): Ultrasonography of the abdomen was performed in $8 / 10(80 \%)$ patients, computed tomography of the abdomen in $4 / 10$ cases $(40 \%)$. MRCP/ MRI was performed in $4 / 10$ cases $(40 \%)$. Pre-operative diagnosis of hydatid cyst was possible in $7 / 10$ cases (70\%). Out of eight cases of USG,5 (62.5\%) had a preoperative diagnosis, out of four cases of CT-scan able to diagnose pre-operative hydatid cyst in all four cases

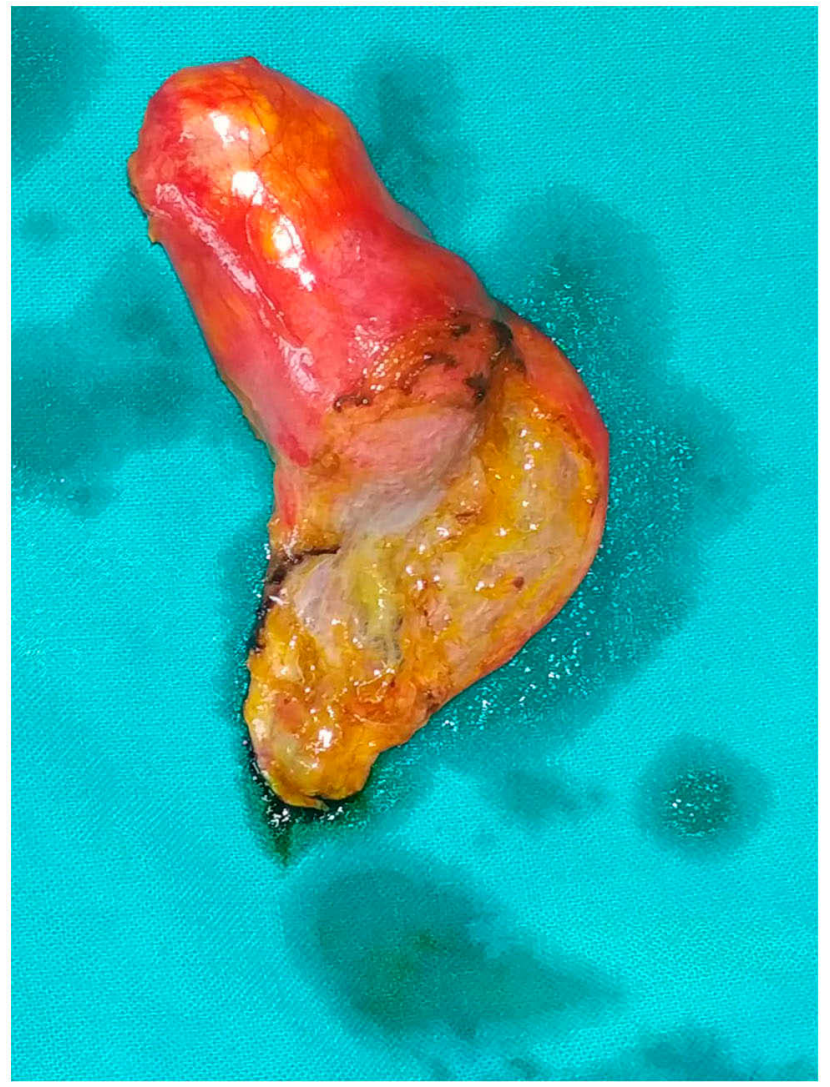

Figure 3 Inflamed deformed gallbladder after resection.

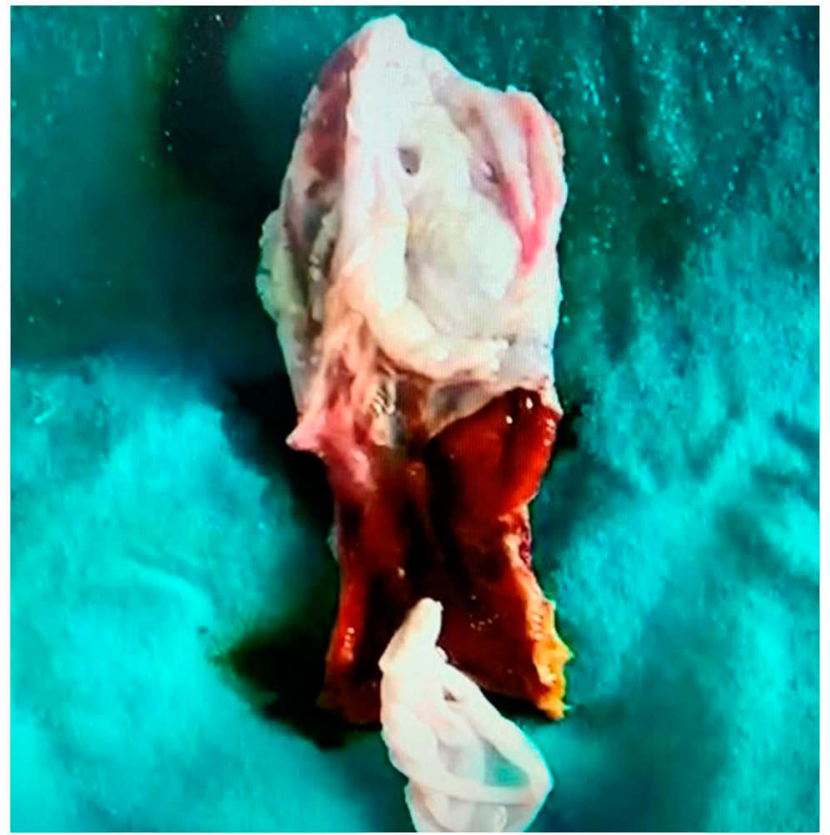

Figure 4 Opened gallbladder specimen with daughter hydatid cyst.

$(100 \%)$. MRCP/MRI was able to diagnose preoperatively in $2 / 4$ cases $(50 \%)$. Only USG was performed in two $(20 \%)$ cases, USG+CT+MRCP was completed in one 
Table I Primary Gallbladder Hydatid Cyst: Clinical Features and Investigations

\begin{tabular}{|c|c|c|c|c|c|}
\hline Authors & $\begin{array}{l}\text { Agel } \\
\text { Sex }\end{array}$ & Clinical Features & $\begin{array}{l}\text { Laboratory } \\
\text { Investigations }\end{array}$ & Imaging Studies & Serology \\
\hline Yagnik et al (2020) & $35 / F$ & RUQ Pain, Nausea, vomiting & Normal & $\begin{array}{l}\text { USG: Cystic lesion (right. lobe liver) } \\
\text { CT: Cystic lesion in liver segment IVa/IVb } \\
(2.3 \times 2.3 \times 2.4 \mathrm{~cm})\end{array}$ & Not done \\
\hline Uzunoglu $^{6}(2016)$ & $68 / \mathrm{M}$ & RUQ pain, lump. Murphy's sign & Mild leukocytosis & USG: Acute cholecystitis & ND \\
\hline Kabiraj et $\mathrm{al}^{7}(2015)$ & $16 / F$ & $\begin{array}{l}\text { RUQ pain, nausea, lump, } \\
\text { Murphy's sign }\end{array}$ & Normal & $\begin{array}{l}\text { USG: Double gallbladder } \\
\text { CT: GB Hydatid }\end{array}$ & Negative \\
\hline Noomene et al ${ }^{8}(2013)$ & $32 / \mathrm{F}$ & $\begin{array}{l}\text { Abdominal pain, nausea, } \\
\text { vomiting, Murphy's sign }\end{array}$ & Normal & $\begin{array}{l}\text { USG, CT: Inflammatory GB } \\
\text { MRCP: Hydatid }\end{array}$ & Negative \\
\hline Rabbani et $\mathrm{al}^{9}(201 \mathrm{l})$ & $38 / \mathrm{M}$ & $\begin{array}{l}\text { Fever, abdominal pain, nausea, } \\
\text { vomiting, } \\
\text { Murphy's sign }\end{array}$ & $\begin{array}{l}\text { Eosinophilia, } \\
\text { Leukocytosis }\end{array}$ & USG: Hydatid cyst of the GB $(5 \times 3 \mathrm{~cm})$ & Not done \\
\hline Krasniqui et al $^{10}(20 \mid 0)$ & $39 / F$ & $\begin{array}{l}\text { Abdominal pain, nausea, } \\
\text { Murphy's sign }\end{array}$ & Normal & $\begin{array}{l}\text { X-ray: calcified opacity } \\
\text { USG and CT: calcified hydatid cyst }(7 \times 5 \mathrm{~cm})\end{array}$ & Not done \\
\hline Pitiakoudis et al' (2006) & $60 / M$ & RUQ pain, fever, vomiting & Leukocytosis, & $\begin{array}{l}\text { USG: Liver hydatid } \\
\text { CT: abnormal GB } \\
\text { with calcified stone } \\
\text { MRCP: (?) Inflammatory } \\
\text { (?) neoplastic cyst }\end{array}$ & Not done \\
\hline Wani et al ${ }^{12}(2005)$ & $51 / \mathrm{F}$ & RUQ Abdominal pain & NA & USG: cholelithiasis & Not done \\
\hline Safioleas et a $\left.\right|^{13}$ (2004) & $61 / F$ & $\begin{array}{l}\text { Abdominal pain, nausea, and } \\
\text { vomiting }\end{array}$ & Normal & X-ray, Barium meal and cholangiography & Not done \\
\hline Safioleas et a $\left.\right|^{13}$ (2004) & $51 / \mathrm{F}$ & Abdominal pain & Eosinophilia & X-ray, Barium meal and USG & Not done \\
\hline Safioleas et al ${ }^{13}$ (2004) & $63 / F$ & Abdominal pain and dyspepsia & Eosinophilia & $\begin{array}{l}\text { X-ray, CT: Hydatid } \\
5 \times 4 \times 5 \mathrm{~cm}\end{array}$ & Positive \\
\hline Kapoor et al ${ }^{14}(2000)$ & $53 / \mathrm{M}$ & $\begin{array}{l}\text { RUQ pain, fever, and jaundice, } \\
\text { Lump }\end{array}$ & Altered LFT & USG: Ruptured hydatid cyst & Positive \\
\hline Rigas et al ${ }^{15}(1979)$ & $65 / F$ & $\begin{array}{l}\text { Abdominal pain, nausea, } \\
\text { vomiting }\end{array}$ & Normal & $\begin{array}{l}\text { Barium meal, X-ray chest, liver scan, and } \\
\text { cholangiogram: Filling defect in the GB }\end{array}$ & Not done \\
\hline
\end{tabular}

Abbreviations: RUQ, Right upper quadrant; USG, Ultrasonography; GB, Gallbladder; CT, computed tomography; MRCP, Magnetic resonance cholangiopancreatography; ND, no details; NA, not available; LFT, liver function tests.

$(10 \%)$ cases, USG+CT in two cases (20\%). USG $+\mathrm{MRCP} /$ MRI in three cases (30\%). Only CT-scan was performed in one case $(10 \%)$.

\section{Medical Treatment}

PGBHC (Table 2): Six patients $(46.15 \%)$ had received post-operative Albendazole therapy. The maximum duration of therapy reported in this group was four months.

SGBHC (Table 4): Pre-operative albendazole therapy was received by two patients $(20 \%)$, and seven patients received post-operative albendazole therapy. The maximum duration of treatment reported in this group was nine months.

\section{Surgery}

PGBHC (Table 2): Nine (76.92\%) patients underwent open cholecystectomy. Open cholecystectomy with pericystectomy was performed in two $(15.38 \%)$ patients, while one $(7.69 \%)$ patient underwent laparoscopic cholecystectomy. One patient underwent ERCP plus stenting.

SGBHC (Table 4): Three patients (30\%) underwent cholecystectomy, while one each underwent pericystectomy and fistula closure, open cholecystectomy with right lobe enucleation, open cholecystectomy with total cyst resection (thoracotomy), PAIR (puncture-aspirationinjection-reaspiration) followed by cholecystectomy, ERCP followed by laparoscopic cholecystectomy, and 
Table 2 Primary Gallbladder Hydatid Cyst: Management and Follow-Up

\begin{tabular}{|c|c|c|c|c|c|}
\hline Authors & Medical Therapy & Surgery & Hospital Stay & $\begin{array}{l}\text { Follow- } \\
\text { Up }\end{array}$ & Recurrence \\
\hline Yagnik et al & No & Laparoscopic cholecystectomy & 3 & $3 \mathrm{mo}$ & No \\
\hline Uzunoglu $M Y^{6}$ & Yes (ND) & Open cholecystectomy & 4 & $6 \mathrm{mo}$ & No \\
\hline Kabiraj et $\mathrm{al}^{7}$ & Yes (ND) & Open cholecystectomy & 10 & $6 \mathrm{mo}$ & No \\
\hline Noomene et $\mathrm{al}^{8}$ & Not given & Open cholecystectomy & 4 & $6 \mathrm{mo}$ & No \\
\hline Rabbani et $\mathrm{al}^{9}$ & $\begin{array}{l}\text { Yes, } 3 \text { cycles, } 21 \text { days. } 10 \text { days } \\
\text { interval }\end{array}$ & $\begin{array}{l}\text { Open cholecystectomy with } \\
\text { Pericystectomy }\end{array}$ & 8 & 2 years & No \\
\hline Krasniqui et al ${ }^{10}$ & $\begin{array}{l}\text { Yes, } 2 \text { cycles, } 21 \text { days, } 14 \text { days } \\
\text { interval }\end{array}$ & $\begin{array}{l}\text { Open cholecystectomy with } \\
\text { Pericystectomy }\end{array}$ & 7 & 5 years & No \\
\hline Pitiakoudis et al" & Yes (4 mo) & Open cholecystectomy & 12 & 2 years & No \\
\hline Wani et al ${ }^{12}$ & Not given & Open cholecystectomy & ND & ND & No \\
\hline Safioleas et $\mathrm{al}^{13}$ & Not given & Open cholecystectomy & ND & 10 years & No \\
\hline Safioleas et $\mathrm{al}^{13}$ & Not given & Open cholecystectomy & 7 & 6 years & No \\
\hline Safioleas et $\mathrm{al}^{13}$ & Yes $(2 \mathrm{mo})$ & Open cholecystectomy & 10 & 4 years & No \\
\hline Kapoor et al ${ }^{14}$ & No & $\mathrm{ERCP}+$ Stenting & $\begin{array}{l}\text { Sepsis expired } \\
\text { on day } 5\end{array}$ & - & - \\
\hline Rigas et al ${ }^{15}$ & No & Open cholecystectomy & 9 & $8 \mathrm{mo}$ & No \\
\hline
\end{tabular}

Abbreviations: ND, no details; mo, months; ERCP, Endoscopic retrograde cholangiopancreatography.

cystotomy with cholecystectomy with choledochoduodenostomy. One patient refused surgery.

In the PGBHC group, hospital stay varied from 3-12 days with a mean of 7.4 days (Table 2). In the SGBHC group, hospital stays of one and 12 days were documented in two cases only (Table 4).

\section{Follow-Up and Recurrence}

Follow-up duration for the PGBHC group ranged between three months and ten years with an average of 34.27 months (Table 2). For the SGBHC group, follow-up ranged from one month to two years with an average of 10.16 months (Table 4). No recurrence was reported at follow-up for both types (Tables 2 and 4).

\section{Discussion}

Hydatid disease in extra-hepatic locations usually remains asymptomatic unless it grows in size and produces pressure symptoms or develops complications like rupture, secondary infection, and an allergic reaction. ${ }^{26} \mathrm{GBHC}$, whether primary or secondary, is extremely uncommon even in areas where hydatid disease is endemic. We performed an extensive literature search and found 22 cases of isolated or primary gallbladder hydatid cyst and 25 cases of secondary involvement. Detailed clinical data were available in 23 cases. In contrast, data could not be extracted in the other 25 cases, as ten reports with 14 cases were not published in English. ${ }^{27-36}$ Six original articles ${ }^{37-42}$ with 10 case reports and one case report ${ }^{43}$ in English where exact details for the particular case were difficult to obtain. We made a detailed analysis of 20 papers comprising 22 cases plus our case. Only one systematic review on hydatid cyst of the gallbladder has been performed till date. ${ }^{44}$ Limitations with that review are misinterpretation of a few original reports: preoperative imaging findings were missing, and there was lack of clarity about primary and secondary hydatid cyst of the gallbladder.

Although found in all age groups, GBHC is common in adulthood. ${ }^{45}$ In this review, cases were detected between the ages of 16 and 76 years, the mean age of incidence being 48.30 years.

Females are commonly affected possibly because of their involvement in food preparation and domestic pet care. ${ }^{46} \mathrm{In}$ this review, we noted that for PGBHC, females are more commonly affected while for SGBHC, there is a slight male preponderance. However, overall, the patients reviewed were mostly females $(56.52 \%)$. 
Table 3 Secondary Gallbladder Hydatid Cyst: Clinical Features and Investigations

\begin{tabular}{|c|c|c|c|c|c|}
\hline Authors & $\begin{array}{l}\text { Agel } \\
\text { Sex }\end{array}$ & Clinical Features & $\begin{array}{l}\text { Laboratory } \\
\text { Investigations }\end{array}$ & Imaging Studies & Serology \\
\hline Jain $\mathrm{G}$ et $\mathrm{al}^{16}$ (2019) & $60 / M$ & $\begin{array}{l}\text { Abdominal pain, anorexia, weight } \\
\text { loss, nausea }\end{array}$ & $\begin{array}{l}\text { Normal } \\
\text { FNAC: Hydatid } \\
\text { cyst }\end{array}$ & $\begin{array}{l}\text { USG: } G B \text { mass }(4 \times 3 \mathrm{~cm}) \text { with liver cyst } \\
\text { MRI: } C a \mathrm{~GB} \text { with liver metastases }\end{array}$ & Positive \\
\hline Yücesoy et $\mathrm{al}^{17}(2014)$ & $58 / M$ & $\begin{array}{l}\text { Abdominal pain, nausea, vomiting, } \\
\text { fever, jaundice, lump, weight loss }\end{array}$ & Altered LFT & $\begin{array}{l}\text { USG and MRCP: GB with liver hydatid }(10 \mathrm{~cm} \\
\text { liver; mm-size filling defects in } \mathrm{GB}) \text {. Dilated } \mathrm{CBD}\end{array}$ & Not done \\
\hline Ertem et $\mathrm{al}^{18}(2012)$ & $48 / M$ & $\begin{array}{l}\text { Abdominal pain, jaundice, } \\
\text { Murphy's sign }\end{array}$ & $\begin{array}{l}\text { Altered LFT, } \\
\text { leukocytosis }\end{array}$ & $\begin{array}{l}\text { USG: Distended GB, dilated CBD, cyst in segment } \\
\text { IVb } \\
\text { CT: cyst in the liver (IVb), CBD stone hydatid (ND) } \\
\text { MRCP: Obstructed CBD }\end{array}$ & Positive \\
\hline Mushtaque et al ${ }^{19}(201 \mathrm{I})$ & $70 / F$ & RUQ pain, lump and dyspepsia & Normal & $\begin{array}{l}\text { USG \& CECT } \\
\text { Liver plus gallbladder cyst hydatid }(11 \times 12 \mathrm{~cm}, 6 \times 7 \mathrm{~cm})\end{array}$ & Positive \\
\hline Murtaza et $\mathrm{al}^{20}(2008)$ & $32 / F$ & $\begin{array}{l}\text { RUQ pain, past jaundice h/o liver } \\
\text { hydatid, Hepatomegaly }\end{array}$ & Altered LFT & USG: Hydatid cyst of liver (ND) & Not done \\
\hline Sabat et $\mathrm{al}^{21}(2008)$ & $35 / F$ & Epigastric pain, jaundice, fever & Altered LFT & $\begin{array}{l}\text { USG: Liver hydatid cyst } \\
\text { CT: Hydatid cyst with communication with GB }\end{array}$ & Not done \\
\hline Adaletlil $^{22}(2005)$ & $46 / M$ & RUQ pain, fever, jaundice & Altered LFT & $\begin{array}{l}\text { USG: Cystic lesion in liver; GB normal } \\
\text { MRCP: Fistulous connection between cyst and GB } \\
\text { ERCP: No communication }\end{array}$ & Not done \\
\hline Kumar et $\mathrm{al}^{23}(2004)$ & $27 / F$ & $\begin{array}{l}\text { Abdominal pain } \\
\text { Past history of liver hydatid }\end{array}$ & Normal & CT: Cyst into segment IV and VII (Hydatid) & Not done \\
\hline Raza et $\mathrm{al}^{24}(2003)$ & $27 / M$ & $\begin{array}{l}\text { Abdominal pain, dyspepsia } \\
\text { hepatomegaly }\end{array}$ & NA & USG: GB stone & Not done \\
\hline BarónUrbano ${ }^{25}$ (1978) & 76 & $\begin{array}{l}\text { Abdominal pain, jaundice, } \\
\text { hepatomegaly }\end{array}$ & Altered LFT & NA & NA \\
\hline
\end{tabular}

Abbreviations: FNAC, Fine Needle Aspiration Cytology; USG, Ultrasonography; GB, Gallbladder; MRI, Magnetic resonance imaging; CT, Computed tomography; CECT, Contrast enhanced computed tomography; Ca, Cancer; LFT, liver function tests; MRCP, Magnetic resonance cholangiopancreatography; RUQ, Right upper quadrant; h/o, History of; CBD, Common bile duct; ERCP, Endoscopic retrograde cholangiopancreatography; ND, no details; NA, not available.

\section{Pathogenesis}

\section{Primary GB Hydatid}

The gallbladder hydatid cyst may be located either in the lumen or externally on the surface. Cangiotti et $\mathrm{al}^{40}$ theorized that gallbladder hydatid cyst occurs due to spread of the brood capsules through the biliary tract. This theory fails to explain the external surface location of the cyst. Rigas et $\mathrm{al}^{15}$ proposed lymphatic circulation as an additional route. Safioleas et $\mathrm{al}^{13}$ also agree with the lymphatic route of spread as their three cases had external surface cysts. Lymphatic spread may explain intraluminal location too. Another rare mechanism is contamination of the gallbladder during surgery for hepatic hydatid cyst. ${ }^{8}$ Makni et al also supported the route of lymphatic spread for any intrabdominal extra-hepatic hydatid cyst. ${ }^{47}$

\section{Secondary GB Hydatid}

SGBHC is likely due to the intrabiliary rupture of hepatic hydatid cyst. Harold Dew first reported intrabiliary rupture in
$1936 .^{48}$ Rupture may be either frank or occult rupture; frank rupture results in obstructive jaundice, cholangitis or pancreatitis, while occult rupture may cause a biliary fistula.

The gallbladder hydatid cyst produces nonspecific symptoms commonly related to size of the cyst. In a series of 27 patients with extra-hepatic cysts reported by Balik et al, ${ }^{49} 21$ patients $(77 \%)$ were asymptomatic. The clinical features of primary isolated extra-hepatic hydatid cyst are highly polymorphic. A large cyst usually causes abdominal pain. The most frequent clinical manifestation was abdominal pain (23/ 23) (100\%). Nausea/vomiting and Murphy's sign were common clinical findings in the PGBHC group, while fever and jaundice were common in the SGBHC group.

\section{Laboratory Investigations}

Routine Blood Tests are Not Specific for Diagnosis

In PGBHC: $50 \%$ of patients had regular laboratory investigations. Eosinophilia was seen in $25 \%$ cases. The probable 
Table 4 Secondary Gallbladder Hydatid Cyst: Management and Follow-Up

\begin{tabular}{|c|c|c|c|c|c|}
\hline Authors & Medical Therapy & Surgery & $\begin{array}{l}\text { Hospital } \\
\text { Stay }\end{array}$ & $\begin{array}{l}\text { Follow- } \\
\text { Up }\end{array}$ & Recurrence \\
\hline Jain $G$ et $\mathrm{al}^{16}$ & $\begin{array}{l}\text { Yes (I mo with } 2 \text { wks pause for } \\
3 \mathrm{mo} \text { ) }\end{array}$ & Not done (Patient refused surgery) & - & I year & No \\
\hline Yücesoy et al ${ }^{17}$ & Yes (8 wks) & $\begin{array}{l}\text { Cystotomy with Cholecystectomy with } \\
\text { choledochoduodenostomy }\end{array}$ & ND & ND & ND \\
\hline Ertem et $\mathrm{al}^{18}$ & Yes (ND) & ERCP stenting then Lap cholecystectomy & 1 & ND & ND \\
\hline Mushtaque et al ${ }^{19}$ & $\begin{array}{l}\text { Preop }(4 \text { wks })+\text { postop }(3 \\
\text { cycles, } 2 \text { I days with I wk } \\
\text { pause) }\end{array}$ & $\begin{array}{l}\text { Cholecystectomy and partial cystectomy and } \\
\text { closure of cystobiliary communication. }\end{array}$ & 12 & $3 \mathrm{mo}$ & No \\
\hline Murtaza et $\mathrm{al}^{20}$ & $\begin{array}{l}\text { Preop ( } 2 \text { wks) Albendazole }+ \\
\text { postop (ND) }\end{array}$ & $\begin{array}{l}\text { Subtotal cholecystectomy with fistulous } \\
\text { opening closure }\end{array}$ & ND & 2 years & No \\
\hline Sabat et $\mathrm{al}^{21}$ & Yes $(9 \mathrm{mo})$ & PAIR followed by cholecystectomy & ND & $9 \mathrm{mo}$ & No \\
\hline Adaletli $^{22}$ & ND & Surgery & ND & ND & ND \\
\hline Kumar et $\mathrm{al}^{23}$ & Yes $(4 \mathrm{mo})$ & $\begin{array}{l}\text { Partial pericystectomy with cholecystectomy } \\
\text { and fistula closure (Seg IV); PAIR for seg VII }\end{array}$ & ND & I year & No \\
\hline Raza et $\mathrm{al}^{24}$ & Yes & Open cholecystectomy with rt lobe enucleation & ND & I mo & No \\
\hline $\begin{array}{l}\text { Barón Urbano } \\
\text { et a }\left.\right|^{25}\end{array}$ & No & $\begin{array}{l}\text { Open cholecystectomy with total cyst resection } \\
\text { (thoracotomy) }\end{array}$ & NA & NA & NA \\
\hline
\end{tabular}

Abbreviations: preop, preoperative; postop, Post-operative; ND, no details; NA, not available; ERCP, Endoscopic retrograde cholangiopancreatography, mo, month/s; wk, week/s; PAIR, puncture aspiration injection re-aspiration; seg, segment.

reason is that hydatid cyst is associated with intermittent eosinophilia ${ }^{50-52}$ likely due to spontaneous leakage from the hydatid cyst or occult rupture into the biliary tract. ${ }^{53}$ However, clinically significant hydatid cyst rupture is associated with transient suppression of the eosinophil count, and that explains normal eosinophil count in secondary GB hydatid cyst. ${ }^{54,55}$ From this review, we suggest that eosinophilia has very low sensitivity in the diagnosis of hydatid infection. Leukocytosis was also observed in $25 \%$ of cases. Altered liver function tests was seen in one patient (7.69\%). The reason for altered LFTs in PGBHC was a rupture of the cyst. In the SGBHC group, six patients had altered LFTs $(66.66 \%)$. Atypical investigations were seen in three patients $(33.33 \%)$.

\section{Serology}

Serology is useful for diagnosis as well as follow-up after either conservative or surgical treatment. ELISA, indirect hemagglutination antibody assay, latex agglutination test, and immunoblot test are the most commonly used immunological methods. ${ }^{56}$ Antigen detection is less sensitive as compared to antibody for circulating E. granulosus. ${ }^{56}$
ELISA appears to be the most sensitive and specific among the available assays. Both disease and parasite have a close association with allergy because of the immunological patterns that contribute to maintaining the larva in its human host, as well as their potential in causing allergic reactions in few patients. Raised IgE level, as well as specific IgE against E. granulosus antigens in the serum of patients with hydatid disease are also key biological features of the disease. ${ }^{57-59}$ Sachar et al also found serology to be a useful test when suspecting intraabdominal hydatid disease. ${ }^{60}$ In their study, serology (IHA) was positive in seven out of eight cases. ${ }^{59}$ Serology was not a routine part of investigation. We found that serology was performed in $7 / 22$ patients. Four patients were from the primary group and three from the secondary group. Among the primary group 50\% patients were positive, while $100 \%$ positivity was seen in secondary GB hydatid. We recommend serology as a part of routine investigation.

Liver hydatid cyst remains asymptomatic for a long period of cystic growth, whereas in PGBHC the patient becomes symptomatic at an earlier phase, and diagnostic imaging shows smaller cysts with deformation of the gallbladder. Hydatid cyst should be included in the differential 
diagnosis of cystic masses in specific organs, especially if an atypical cystic lesion is noted in the liver or lung, particularly in endemic regions. ${ }^{61}$ For USG: Preoperative diagnosis of hydatid cyst was possible in $4 / 10$ cases $(40 \%)$ of PGBHC and 5/8 (62.5\%) of SGBHC. The overall detection rate with USG is $9 / 18(50 \%)$. Three more cases ${ }^{16,22}$ as well as our case had a cystic lesion on USG, and prior suspicion may have increased the detection rate in as many as $12 / 18(66.66 \%)$. CT-scan was able to diagnose preoperative hydatid cyst in $50 \%$ of the PGBHC group and $100 \%$ of the SGBHC group. The overall detection rate was $75 \%$.

Albendazole is widely used as primary treatment in hydatid disease of the liver with good results. ${ }^{62}$ However, it is mostly expected to result in the formation of an abscess in a pulmonary hydatid cyst. Albendazole alone is not reliable for pulmonary hydatid disease. Even if the organism dies, the retained membranes become a source of recurrent infection. ${ }^{63}$ Most reported studies and cases use albendazole as a part of treatment to reduce the chances of spillage causing serious anaphylactic reaction ${ }^{64}$ or dissemination at surgery, ${ }^{19}$ as also postoperatively to reduce the chances of recurrence. ${ }^{19}$ In this review, preoperative therapy was received by only two patients $(8.69 \%)$ and postoperative by $56.52 \%$ of patients. A few studies are available in the literature that reported the rupture of the cyst hydatid during and after the cessation of medical treatment. ${ }^{65}$ A cyst can maintain its viability despite the high concentration of albendazole in the serum and cyst fluid; moreover, protoscolices may remain viable in a dead cyst. ${ }^{66,67}$ No severe anaphylactic reaction or recurrence was reported in the reviewed literature. Therefore, from this review, we feel that albendazole monotherapy has a questionable role for extra-hepatic hydatid cyst and it may be better to avoid such therapy, though it forms an integral adjunct to surgery.

The most common therapeutic approach in the present review is open cholecystectomy. Only a single case by Ertem et $\mathrm{al}^{18}$ was operated by laparoscopic technique. The majority of surgeons preferred the open approach due to fear of rupture and spillage. But nowadays, in experienced hands laparoscopy is as safe as the open procedure for hydatid disease with the advantage of minimal access surgery. Although open procedures have usually been performed for the surgical treatment of hydatid disease, laparoscopic approaches have become popular in recent years. A recent study conducted by Bektasoglu et al found that laparoscopy is safe. Laparoscopy is a safe and feasible approach for the surgical treatment of liver hydatidosis. ${ }^{68}$ It is possible to treat most of these parasitic cysts using minimally invasive techniques both safely and effectively, particularly for liver hydatid cyst. ${ }^{69}$ Until further evidence is available, open cholecystectomy remains the standard of care.

It appears from our review that PGBHC and SGBHC have sufficiently distinct presentations and behavior to merit consideration as different though related conditions. Contrasting them rather than clubbing them together may throw up further evidence to help optimize their management.

\section{Conclusion}

GBHC, either primary or secondary, is a rare condition. The most common clinical manifestation is abdominal pain. Eosinophilia has very low sensitivity, while serology is very helpful in suspected GBHC. Liver function tests were altered mainly in SGBHC. A high degree of suspicion is required to diagnose GBHC preoperatively on USG or CT-scan imaging. Hydatid cyst should be included in the differential diagnosis of any cystic lesion in specific organs found in patients from an endemic area. Albendazole has a questionable role in GBHC, whether primary or secondary, and it is better avoided. GBHC can also be managed laparoscopically. However, till more evidence is available, open cholecystectomy remains the standard of care.

In view of the different etiopathologies behind primary and secondary GBHC, as well as their dissimilar clinical behavior and investigative profiles, we recommend that future reports and studies recognize this distinction in their analyses.

\section{Acknowledgments}

The patient described in this review has provided written informed consent for the publishing of case details and accompanying images.

\section{Institutional Approval}

Institutional approval is neither applicable nor required for publication of this manuscript.

\section{Disclosure}

The authors report no conflicts of interest in this work.

\section{References}

1. Budke CM, Deplazes P, Torgerson PR. Global socioeconomic impact of cystic echinococcosis. Emerg Infect Dis. 2006;12:56-64. doi:10. 3201/eid1202.050499 
2. Lucas SB. Other viral and infectious diseases and HIV-related liver disease. In: MacSween RNM, Burt A, Portmann B, Ferrell L, editors. Pathology of the Liver. London: Churchill Livingstone; 2012:437-438.

3. Mushtaque M, Mir MF, Malik AA, Arif SH, Khanday SA, Dar RA. Atypical localizations of hydatid disease: experience from a single institute. Niger J Surg. 2012;18(1):2-7. doi:10.4103/1117-6806.95466

4. Safioleas M, Stamoulis I, Theoqaris S, Moulakakis K, Makris S, Kostakis A. Primary hydatid disease of the gallbladder: a rare clinical entity. J Hepatopancreat Surg. 2004;11:352-356.

5. Liberati A, Altman DG, Tetzlaff J, et al. The PRISMA statement for reporting systematic reviews and meta-analyses of studies that evaluate health care interventions: explanation and elaboration. PLoS Med. 2009;6:e1000100. doi:10.1371/journal.pmed.1000100

6. Uzunoglu M, Altintoprak F, Dikicier E, Zengin I, Celik A. Hydatid disease in the gallbladder: a rare location. J Med Cases. 2016;7 (12):522-523. doi:10.14740/jmc2501w

7. Kabiraj P, Kuiri SS, De U. Primary hydatid cyst of gallbladder: a case report. Int J Case Rep Images. 2015;6(7):440-443. doi:10.5348/ijcri201574-CR-10535

8. Noomene R, Ben Maamer A, Bouhafa A, Haoues N, Oueslati A, Cherif A. Primary hydatid cyst of the gallbladder: an unusual localization diagnosed by magnetic resonance imaging (MRI). Pan Afr Med J. 2013;14:15. doi:10.11604/pamj.2013.14.15.1424

9. Rabbani K, Narjis Y, Louzi A, Benelkhaiat R, Jalal H, Finech B. Unusual localization of hydatidosis: hydatid cyst of gallbladder. Ann Tropical Med Pub Health. 2011;4:119-121. doi:10.4103/17556783.85766

10. Krasniqi A, Limani D, Gashi-Luci L, Spahija G, Dreshaj IA. Primary hydatid cyst of the gallbladder: a case report. J Med Case Rep. 2010;4:29. doi:10.1186/1752-1947-4-29

11. Pitiakoudis MS, Tsaroucha AK, Deftereos S, Laftsidis P, Prassopoulos P, Simopoulos CE. Primary hydatid disease in a retroplaced gallbladder. J Gastrointestin Liver Dis. 2006; 15:383-385.

12. Wani RA, Malik AA, Chowdri NA, Wani KA, Naqash SH. Primary extrahepatic abdominal hydatidosis. Int J Surg. 2005;3:125-127. doi:10.1016/j.ijsu.2005.06.004

13. Safioleas M, Stamoulis I, Theocharis S, Moulakakis K, Makris S, Kostakis A. Primary hydatid disease of the gallbladder: a rare clinical entity. J Hepatobiliary Pancreat Surg. 2004;11:352-356. doi:10.1007/ s00534-004-0915-6

14. Kapoor A, Sarma D, Gandhi D. Sonographic diagnosis of a ruptured primary hydatid cyst of the gallbladder. $J$ Clin Ultrasound. 2000;28:51-52. doi:10.1002/(SICI)1097-0096(200001)28:1<51::AIDJCU9>3.0.CO;2-8

15. Rigas AM, Karatzas GM, Markidis NC, Bonikos DS, Sotiropoulou GG, Skalkeas G. Primary hydatid cyst of the gallbladder. Br J Surg. 1979;66:406. doi:10.1002/bjs.1800660609

16. Jain G, Kumar C, Meena P, et al. Hydatid cyst of gallbladder masquerading as carcinoma: a rare case report with review of literature. Intractable Rare Dis Res. 2019;8(1):36-42. doi:10.5582/ irdr.2018.01097

17. Yücesoy AN, Poçan S. Secondary gallbladder hydatidosis and nonfragmented germinative membrane sourced obstructive jaundice caused by intrabiliary ruptured hepatic hydatid cyst (a case report): two rare complications of the intrabiliary ruptured hepatic hydatid cyst. Hepatobiliary Surg Nutr. 2014;3:209-211. doi:10.3978/j. issn.2304-3881.2014.07.05

18. Ertem M, Aytaç E, Karaduman Z. Cystic hydatid disease of the gallbladder. Turk J Gastroenterol. 2012;23:825-826. doi:10.4318/ tjg. 2012.0440

19. Mushtaque M, Malik AA, Malik RA. Hydatid cyst of the gallbladder: a rare location. Eastern J Med. 2011;16:83-86.

20. Murtaza B, Malik IB, Mahmood A, Sharif MA, Saeed S, Satti AA. Cholecysto-hydatid cyst fistula. J Coll Physicians Surg Pak. 2008;18:778-780. doi:10.2008/JCPSP.778780
21. Sabat SB, Barhate KP, Deshmukh MP. Cholecysto-hydatid cystfistula. J Ultrasound Med. 2008;27:299-301. doi:10.7863/ jum.2008.27.2.299

22. Adaletli I, Yilmaz S, Cakir Y, Kervancioglu R, Bayram M. Fistulous communication between a hepatic hydatid cyst and the gallbladder: diagnosis with MR cholangiopancreatography. Am J Roentgenol. 2005;185(5):1211-1213. doi:10.2214/AJR.04.1270

23. Kumar A, Upadhyaya DN, Singh S, Kumar M, Ansari MA. Cholecysto-hydatid cyst fistula. Indian $J$ Gastroenterol. 2004;23:76-77.

24. Raza MH, Harris SH, Khan R. Hydatid cyst of gallbladder. Indian $J$ Gastroenterol. 2003;22:67-68.

25. Barón Urbano C, Diego Estévez M, Pascual Montero J, Suberviola Gómez E. Ectopia of the gallbladder associated with hepatic hydatidosis. Rev Esp Enferm Apar Dig. 1978;53:691-698.

26. Tsaroucha AK, Polychronidis AC, Lyrantzopoulos N, et al. Hydatid disease of the abdomen and other locations. World J Surg. 2005;29:1161-1165. doi:10.1007/s00268-005-7775-3

27. Gillet M, Runser C, Monange C, et al. Migration of daughter cysts into the common bile duct and gallbladder hydatid cyst of the liver. Emergency surgery. Apropos of 3 cases. Ann Chir. 1973;27:831-838. [article in French].

28. Ivanis N, Rubinić M, Gudović A, Zeidler F. Ultrasound image of an echinococcus daughter cyst in the gallbladder. Ultraschall Med. 1994;15:269-271. [article in German].

29. Khokhlov NF. Echinococcosis of gallbladder and bile ducts. Sov Zdravookhr Kirg. 1967;3:26-27. [article in Russian].

30. Mizaushev BA, Emuzov S. Rare case of acute phlegmonous cholecystitis in combination with echinococcosis of the gallbladder and mechanical jaundice. Vestn Khir Im I I Grek. 1979;122:93-94. [article in Russian].

31. Pautov FN. A case of primary alveolar echinococcosis of the gallbladder. Med Parazitol (Mosk). 1964;33:423-425. [Article in Russian].

32. Seror J, Rives J, Azoulay C. Common bile duct obstruction caused by hydatid gallbladder revealed by systematic examination of the bile ducts: importance of radiomanometry in hydatid cysts of the liver with biliary content; excellent results of an ideal choledochotomy. Afr Fr Chir. 1958;16:367-370. [article in French].

33. Tkebuchava GI. Calcified echinococcosis of the gallbladder. Khirurgiia (Mosk). 1966;42:134-135. [article in Russian].

34. Aksu M, Sevimli FK, Ibiloğlu I, Arpacı RB. Cystic echinococcosis in the Mersin province (119 cases). Turkiye Parazitol Derg. 2013;37:252-256. [article in Turkish]. doi:10.5152/tpd.2013.3193

35. Ansimov AF. On echinococcosis of the gallblader and bile ducts. Khirurgiia (Mosk). 1962;38:106-107. [article in Russian].

36. Khokhlov NF. A case of echinococcosis of the gallbladder. Zdravookhranenie Kazakhstana. 1962;22:72-73. [article in Russian].

37. Gligorievski A. Atypical localizations of hydatid disease: US and CT evaluation. ARC J Radiol Med Imaging. 2018;3(2):4-13.

38. Mushtaque M, Mir MF, Malik AA, Arif SH, Khanday SA, Dar RA. Atypical localizations of hydatid disease: experience from a single institute. Niger J Surg. 2012;18:2-7. doi:10.4103/1117-6806.95466

39. Şişmanlar Eyüboğlu T, Ramaslı Gürsoy T, Tana Aslan A, Pekcan S, Budakoğlu Iİ. Ten-year follow-up of children with hydatid cysts. Turk Pediatri Arsivi. 2019;54(3):173-178. doi:10.14744/ TurkPediatriArs.2019.24119

40. Cangiotti L, Muiesan P, Begni A, et al. Unusual localizations of hydatid disease: a 18 year experience. G Chir. 1994;15:83-86.

41. Gun E, Etit D, Buyuktalanci DO, Cakalagaoglu F. Unusual locations of hydatid disease: a 10-year experience from a tertiary reference center in Western Turkey. Ann Diagn Pathol. 2017;29:37-40. doi:10.1016/j.anndiagpath.2017.01.011

42. Keser SH, Selek A, Ece D, et al. Review of hydatid cyst with focus on cases with unusual locations. Turk Patoloji Derg. 2017;33 (1):30-36. doi:10.5146/tjpath.2016.01369 
43. Abou-Khalil S, Smith BM, MacLean JD, et al. Acute cholecystitis and cholangitis caused by Echinococcus granulosus. Am J Gastroenterol. 1996;91(4):805-807.

44. Gómez R, Allaoua Y, Colmenares R, Gil S, Roquero P, Ramia JM. Hydatid cyst of the gallbaldder: a systematic review of the literature. World J Hepatol. 2016;8(25):1087-1092. doi:10.4254/wjh.v8. i25.1087

45. Özgür T, Kaya ÖA, Hakverdi S, Akın M, Hamamcı B, Yaldız M. Retrospective evaluation of the echinococcosis cases regarding histopathological aspects. Dicle Med J. 2013;40:641-644. doi:10.5798/ diclemedj.0921.2013.04.0348

46. Karaman Ü, Miman Ö, Kara M, Gıcık Y, Aycan ÖM, Atambay M. Hydatid cyst prevalence in the region of Kars. Turk J Parasitol. 2005;29:238-240.

47. Makni A, Jouini M, Kacem M, Safta ZB. Extra-hepatic intra-abdominal hydatid cyst: which characteristic, compared to the hepatic location? Updates Surg. 2013;65(1):25-33. doi:10.1007/ s13304-012-0188-6

48. Dew H. Some complications of hydatid disease. $\mathrm{Br} J$ Surg. 1936;18:275-293. doi:10.1002/bjs.1800187010

49. Balik AA, Celebi F, Basoglu M, et al. Intraabdominal extrahepatic echinococcosis. Surg Today. 2001;31:881-884. doi:10.1007/ s005950170027

50. Baykal K, Onol Y, Iseri C, et al. Diagnosis and treatment of renal hydatid disease: presentation of four cases. Int $J$ Urol. 1996;3:497-500. doi:10.1111/j.1442-2042.1996.tb00584.x

51. Calma CL, Neghina AM, Moldovan R, et al. Cystic echinococcosis in Arad County, Romania. Vector Borne Zoonotic Dis. 2012;12:333-335. doi:10.1089/vbz.2011.0756

52. Fahim F, Al Salamah SM. Cystic echinococcosis in Central Saudi Arabia: a 5-year experience. Turk J Gastroenterol. 2007;18:22-27.

53. Prousalidis J, Kosmidis C, Kapoutzis K, et al. Intrabiliary rupture of hydatid cysts of the liver. Am J Surg. 2009;197:193-198. doi:10.1016/j.amjsurg.2007.10.020

54. Constantin V, Popa F, Socea B, et al. Spontaneous rupture of a splenic hydatid cyst with anaphylaxis in a patient with multi-organ hydatid disease. Chirurgia (Bucur). 2014;109:393-395.

55. Sekiguchi H, Suzuki J, Pritt BS, et al. Coughing up a diagnosis: a cavitary lung lesion with worsening eosinophilia. Am J Med. 2013;126:297-300. doi:10.1016/j.amjmed.2012.12.004

56. McManus DP, Zhang W, Li J, Bartley PB. Echinococcosis. Lancet. 2003;362(9392):1295-1304. doi:10.1016/S0140-6736(03)14573-4
57. Guisantes JA, Vicente-Garcia F, Abril JM, Eraso E, Martinez J. Total and specific IgE levels in human hydatid disease determined by enzyme immunoassay: serological follow-up after surgery. J Investig Allergol Clin Immunol. 1994;4:301-304.

58. Dreweck CM, Luder CG, Soboslay PT, Kern P. Subclass-specific serological reactivity and IgG4-specific antigen recognition in human echinococcosis. Trop Med Int. Health. 1997;2(8):779-787. doi:10.1046/j.1365-3156.1997.d01-385.x

59. Rigano R, Ioppolo S, Ortona E, et al. Long-term serological evaluation of patients with cystic echinococcosis treated with benzimidazole carbamates. Clin Exp Immunol. 2002;129:485-492. doi:10.1046/ j.1365-2249.2002.01925.x

60. Sachar S, Sachar S, Goyal S, Sachar S. Uncommon locations and presentations of hydatid cyst. Ann Med Health Sci Res. 2014;4 (3):447-452. doi:10.4103/2141-9248.133476

61. Malik A, Chandra R, Prasad R, Khanna G, Thukral BB. Imaging appearances of atypical hydatid cysts. Indian J Radiol Imaging. 2016;26:33-39. doi:10.4103/0971-3026.178284

62. Balik AA, Basoglu M, Celebi F, et al. Surgical treatment of hydatid disease of the liver: review of 304 cases. Arch Surg. 1999;134:166-169. doi:10.1001/archsurg.134.2.166

63. Peleg H, Best L, Gainiti D. Simultaneous operation for hydatid cysts of right lung and liver. J Thorac Cardiovasc Surg. 1985;90:783-787. doi:10.1016/S0022-5223(19)38548-4

64. Saenz SPB, Cazana JL, Cobo J, et al. Anaphylactic shock by rupture of hepatic hydatid cyst. Follow-up by specific IgE serum antibodies. Allergy. 1992;47:568-570. doi:10.1111/j.1398-9995.1992.tb00683.x

65. Morris DL, Dykes PW, Dickson B, Marriner SE, Bogan JA, Burrows FGO. Albendazole in hydatid disease. $\mathrm{Br}$ Med $\mathrm{J}$. 1983;286:103-104. doi:10.1136/bmj.286.6359.103-a

66. Saimot AG, Meulemans A, Cremieux AC, et al. Albendazole as a potential treatment for human hydatidosis. Lancet. 1983;17:652-656. doi:10.1016/S0140-6736(83)92533-3

67. Morris DL, Chinnery JB, Georgiou G, Stamatakis G, Golematis B. Penetration of albendazole sulphoxide into hydatid cysts. Gut. 1987;28:75-80. doi:10.1136/gut.28.1.75

68. Bektasoglu HK, Hasbahceci M, Tasci Y, et al. Comparison of laparoscopic and conventional cystotomy/partial cystectomy in treatment of liver hydatidosis. BioMed Res Int. 2019;2019:Article ID 1212404. doi:10.1155/2019/1212404

69. Palanivelu C, Jani K, Malladi V, et al. Laparoscopic management of hepatic hydatid disease. JSLS. 2006;10(1):56-62.

Clinical and Experimental Gastroenterology

Dovepress

\section{Publish your work in this journal}

Clinical and Experimental Gastroenterology is an international, peerreviewed, open access, online journal publishing original research, reports, editorials, reviews and commentaries on all aspects of gastroenterology in the clinic and laboratory. This journal is indexed on American Chemical Society's Chemical Abstracts Service (CAS)
The manuscript management system is completely online and includes a very quick and fair peer-review system, which is all easy to use. Visit http://www.dovepress.com/testimonials.php to read real quotes from published authors. 